\title{
ANALYSIS OF DATA VISUALIZATION IN PANDEMIC SITUATION
}

\author{
Sharmila Gaikwad \\ Assistant Professor \\ Rajiv Gandhi Institute of technology
}

\begin{abstract}
Data visualization is a technique to expand and explore the difficult dataset into diagrammatical, maps and pictorial forms. This paper focuses on data visualization worked in two Era's of pandemic situation such as plague in 1920 and Covid-19 in 2020. In the current scenario we now that data visualization as proven effectively and played vital role in Covid-19. We have examined some techniques and tools which are present in 1920 and 2020. Data visualization has shown his importance to society and also different languages such as python and different tools of big data has done well job. We have seen some different results from data visualization such as destroying chain of virus means that tracking the first person record and stopping him from community transmission.
\end{abstract}

Keywords-Plague, Covid-19 and transmission, Visualization, Centenary, Dashboards.

\section{INTRODUCTION}

Data is generated from any source it can be any type such as words, sentence, paragraph, music, pictures and video etc. Data is stored in a huge databases such as sql, mysql, Mongo $\mathrm{dB}$, Big Data etc. But when it is present the data to the another person is a difficult task. Developer and Analyst of companies is deciding to have a different tools and techniques in system. Due to improvement in technology visualization is changing from one level to next level. Nowadays to represent or visualize a single words or message can be done in innovative way. In this paper we have focused and researched about two pandemic situation and how is the data visualization in current situation of Covid-2019 and in Plague 1920. Did data visualization help the pandemic situation? and How did it help are the question which is explained in this paper.

\section{LITERATURE REVIEW}

This literature survey consists of three sections:

1) Plague Situation in 1920: By the study of Plague by World Health Organizations. Plague is the pandemic situation which is badly effected to major countries such as India, Burma, Indo-Chine and FUKIEN etc. As per the study it says that India was most effected, Statistics of India Plague situation : 1918-1920 (1,702,718)and death percentage is 13.52 . Total count of plague death in India is 12,597,789 from 1898 to 1948.

2) Data visualization Era's: A brief history of data visualization paper or study says that techniques change in

\author{
Jignesh Patil \\ Computer Engineering \\ Rajiv Gandhi Institute of technology
}

the period from $17^{\text {th }}$ Century to $20^{\text {th }}$ Century. This paper is fully is concentrated on the data visualization techniques in the upcoming ERA's.

3) Data Visualization techniques: Zhaio Khadi (National University of Singapore) papers focuses on different techniques of visualization. In this paper visualization techniques of visualization such as $1 \mathrm{D}, 2 \mathrm{D}, 3 \mathrm{D}$ and $4 \mathrm{D}$ technique, they continue in were discussed about (Big data visualization and analytics) in which author saying future research challenges and emerging applications have focused on human machine interaction, Big data and Machine Learning. In this study different authors is speaking on challenges and analytics of data visualization.

\section{Methodology}

\section{1) 1920 Plague:}

Beginning of data visualization in the $17^{\text {th }}$ Centenary is maps and diagram used for navigation and exploration. Different researchers and developers think and plan for visualizing data. First strategy is plotting, theoretical function and logical between the tabulating values. $16^{\text {th }}$ Centenary is the measurement of the distance and space $\rightarrow$ navigational and territorial expansion. $17^{\text {th }}$ Centenary is new graphic form were presented in this ERA researchers start working on the geographical area where cartogram and areas used for visualization data. $18^{\text {th }}$ Centenary is the era of the beginning modern graphics provided by the previous innovation of design and techniques 1801 (Earliest geographical Map) and 1820 (Continuos Shading). $19^{\text {th }}$ Centenary is the Golden age of the statistics graphics and rapid growth of visualization. It is also called as modern dark ages. In these most part on concentrated on the: 1) Many Statisticians found that numbers, parameters estimates and pictures used for standard fact. As seen in the above Centenary data visualization there is no data visualization which is calculated by computer. We can see researchers use graph paper and paper for calculating points from one point to another point was some. In this Centenary no new tools and technology is increasing that's why India was most effected in 1920 plague situation has seen in the literature survey we can understand data visualization technology situation. Due to Lack of data visualization can see the death count in literature survey, If the visualization data and presentation of disease to the world is proper no pandemic situation will be created. In the Era of $19^{\text {th }}$ Centenary data visualization was growing it's strength and power to next level. As per survey most of Data visualization is offline to present the data to world was not sufficient. Visualization is 


\section{International Journal of Engineering Applied Sciences and Technology, 2020 \\ Vol. 5, Issue 7, ISSN No. 2455-2143, Pages 251-254 \\ Published Online November 2020 in IJEAST (http://www.ijeast.com)}

not animation it is scientific study were the true facts or data is collected and stored in database in different statistics and graphical methods used to visualize or present data. Data visualization in Plague 1920 played small role to describe the patients record on paper, it did not prevent any patient from plague.

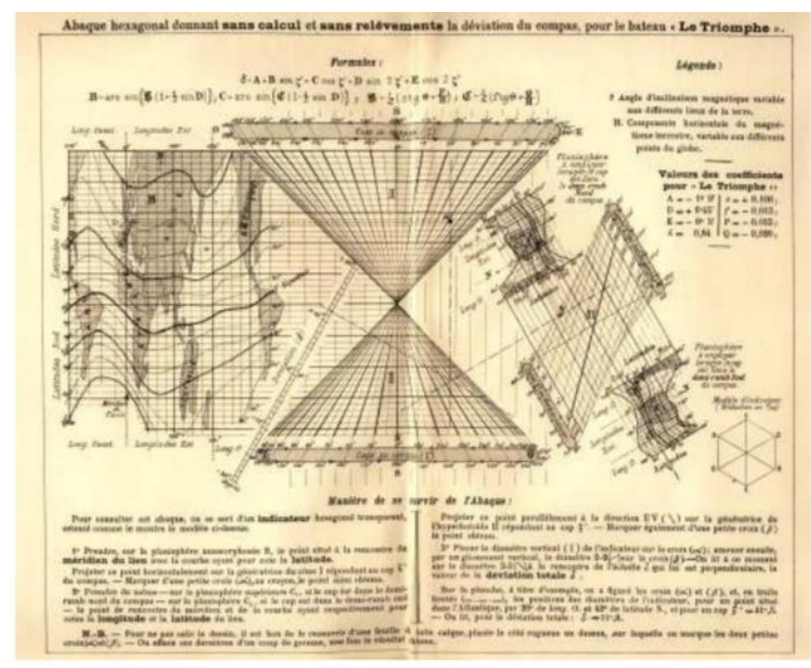

Figure 1 : Graphical Form in $19^{\text {th }}$ Century

As shown in above figure we can see understand visualization is developing in these century. Graphical and Mathematical expression is on the paper. Due to lack of technology visualization cannot be in the form of digital. Since it is the GOLDEN ERA were visualization put his step forward in aggressive and successful way. The death count and total count of plague were counted visualize on the paper in history. Visualizing data and presenting data to world was the difficult to anyone.

2) 2019 COVID pandemic situation :

Covid pandemic situation is creating disaster and proving badly to whole world. Technology has prevent and given some kind of relief to researchers and world. In current scenario big data and data visualization has impacted and played important role. In these situation some points to be noted such as :

1) Big data visualization steps analyzing and visualizing data:

a) Data / Information : Collections of raw data such as words, pictorial format and facts etc.

b) Numerical-Conversion: Normalizing, Logarithms.

c) Data Inspection : Assembling, Measuring etc.

d) Pictorial Expansion : Capacity, Forecast, Clues and symbol etc.

e) User Communication : Plotting, Tagging, Marking, Zooming and Panning .

2) Big data techniques and tools has given new role to companies to analyze the data and maintain the record, information easily. Most companies has created visualization tools and dashboards to visualize the data.
3) Machine Learning, Python and Big data we can say them heart of visualization. For example

a) Calculating the patients in one seconds.

b) Provide details history of the patient.

c) Tracking the travel history.

d) Maintaining cure and uncured patients.

e) And most preventing not affected patients by the COVID-19. Most of people have been "save " by the COVID-19. Can we say E-data visualization has proven effectively in COVID-19.

4) Yes we can see the current situation were the advertisement of COVID-19 is done to the world to single person.

5) Telling and Visualization presentation on websites and TV.

6) Next different application which has given the authority of preventing and explaining COVID-19 scenario.

7) Today world is mainly focusing on Technology and explaining the scenario COVID-19 to each and every person.

8) Data visualization has proven impactful in the world.

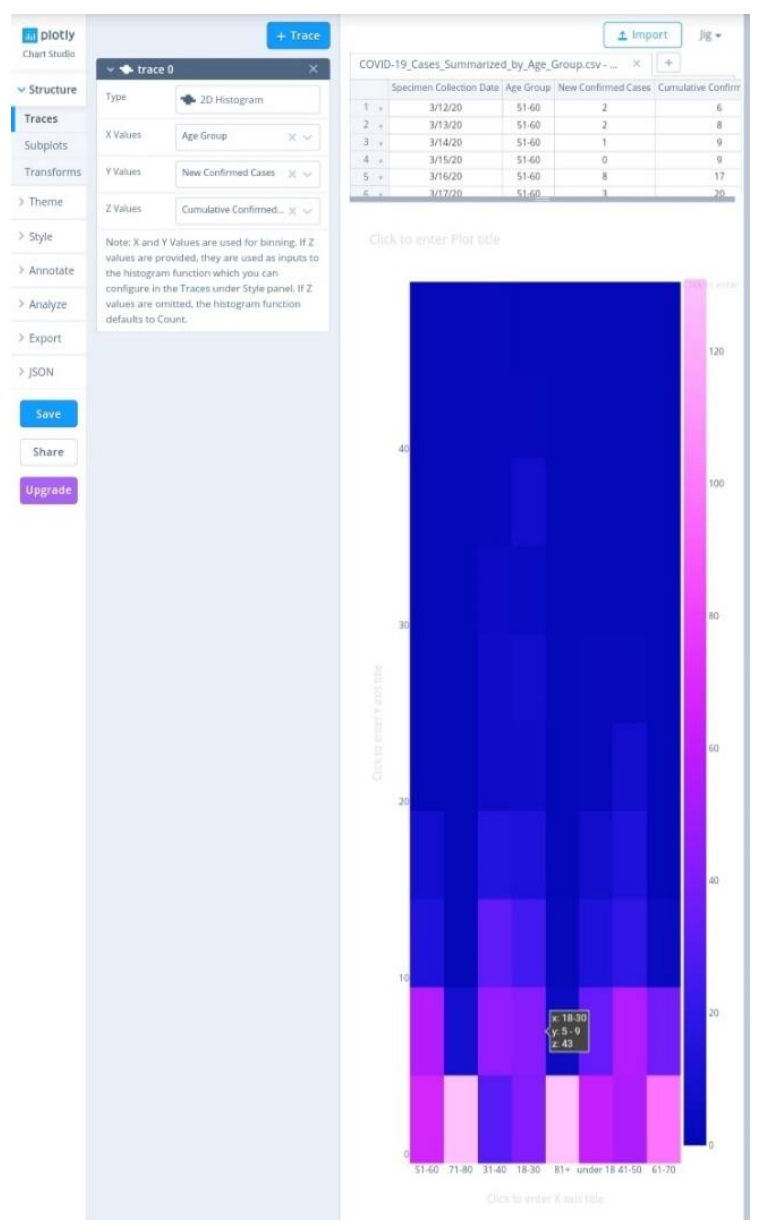

Figure 2 : 2D Histogram 


\section{International Journal of Engineering Applied Sciences and Technology, 2020 \\ Vol. 5, Issue 7, ISSN No. 2455-2143, Pages 251-254 \\ Published Online November 2020 in IJEAST (http://www.ijeast.com)}

In the above figure we can say that technology and tools are increased in a huge way that has support the world. In above figure we have taken dataset of Covid-19 group ages. Next we used the plot-ly chart studio to visualize the dataset. The graphical method used in these is 2D histogram. Different color represent different age of group in the histogram. By Comparing the present situation to 1920 plague we can say that visualization in present situation is the need of the world. We have taken a small example of datasets to explain the present scenario of visualization. Big data, Machine Learning, $\mathrm{AI}$ and python has done terrific job for visualizing the data, to bring visualization in market. Big data consists of main four V's they are value, velocity, volume and variety each feature has given the visualization a new idea to present the data. World in pandemic situation are using the visualization effectively such as companies are using visualization has pillar of company, if they don't visualize in proper way then their product will fail in market. Coming to the point of visualization in pandemic situation as per survey $90 \%$ visualization has done successful work.

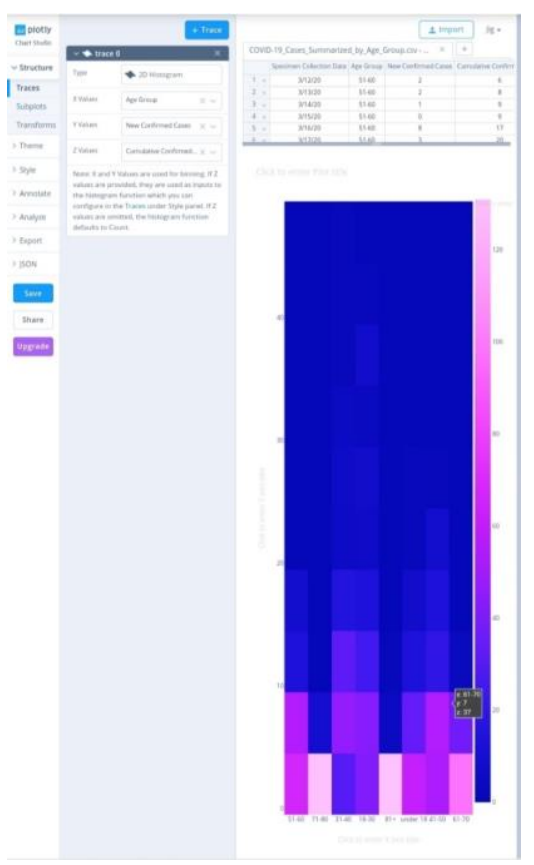

Figure 3 : 2D Histogram

In the above figure 2D histogram graphical form is used for visualizing the dataset. In figure 2 we can see different ages and in present figure we can see different ages.

\section{RESUlT}

Data visualization is increasing and helping pandemic situation COVID-19 successfully. To visualize $\mathrm{n}$ numbers of people through the world is not possible. Visualization is giving the way to the record huge amount patients in a minute. It is been very successful and impactful till now to visualize and cover the Covid-19 to whole the World. Different techniques, tools, Dashboards has been used by researchers by the Countries. It is just not about the visualizing the patients in COVID-19 but is covering the symptoms of COVID-19 with different techniques. Dataset can be large or small but to visualize it is difficult in a normal way. Visualization has shown the importance of its in market that what it can be do. Day by day visualization is improving it's techniques and tools to provide business to become stronger in all departments such as monitoring the business from first level to last level.

\begin{tabular}{|c|c|c|}
\hline $\begin{array}{l}\text { Result } \\
\text { Parameters }\end{array}$ & Plague 1920 & COVID-19 \\
\hline $\begin{array}{l}\text { Effective } \\
\text { communication } \\
\text { world }\end{array}$ & $\begin{array}{l}\text { Less } \\
\text { communication } \\
\text { hence there } \\
\text { was huge } \\
\text { number plague } \\
\text { patients .It was } \\
\text { beginning of } \\
\text { visualization } \\
\text { and } \\
\text { management of } \\
\text { visualization } \\
\text { and techniques } \\
\text { were less. }\end{array}$ & $\begin{array}{l}\text { Communicating and } \\
\text { Connecting the world is } \\
\text { easier due to high } \\
\text { technology. World are } \\
\text { now prepare to fight with } \\
\text { these situation. Software } \\
\text { are making the } \\
\text { visualization techniques } \\
\text { and dashboard to help the } \\
\text { business and researcher to } \\
\text { give relief them }\end{array}$ \\
\hline $\begin{array}{l}\text { Describing } \\
\text { present } \\
\text { Situation }\end{array}$ & $\begin{array}{l}\text { Documentation } \\
\text { and Records } \\
\text { were high but } \\
\text { tools to present } \\
\text { that situation } \\
\text { was improper }\end{array}$ & $\begin{array}{l}\text { Excellent Tools and } \\
\text { techniques to describe the } \\
\text { situation Example Plotly, } \\
\text { Python, Big Data }\end{array}$ \\
\hline $\begin{array}{l}\text { Frequently } \\
\text { Update in } \\
\text { seconds }\end{array}$ & $\begin{array}{l}\text { Less speed and } \\
\text { network } \\
\text { communication }\end{array}$ & $\begin{array}{l}\text { World is connected with } \\
\text { wireless and wired } \\
\text { technology. } \\
\text { generation is about of IOT. } \\
\text { Hence updating the } \\
\text { database is easier. }\end{array}$ \\
\hline $\begin{array}{l}\text { Monitoring } \\
\text { Health and } \\
\text { Travel history } \\
\text { of Patients }\end{array}$ & $\begin{array}{l}\text { Less } \\
\text { technology so } \\
\text { it was difficult } \\
\text { to track the } \\
\text { record patients } \\
\text { database }\end{array}$ & $\begin{array}{l}\text { Due to Big data } \\
\text { researchers and Doctors } \\
\text { can track the patient over } \\
\text { all history. To stop the } \\
\text { community transmission } \\
\text { and removing the effected } \\
\text { patients is easier. }\end{array}$ \\
\hline $\begin{array}{l}\text { Technology } \\
\text { and Tools }\end{array}$ & $\begin{array}{l}\text { Less hardware } \\
\text { and software } \\
\text { were present }\end{array}$ & $\begin{array}{l}\text { Big data, Python, Artificial } \\
\text { Intelligence, Machine- } \\
\text { Learning technology make } \\
\text { the researchers and } \\
\text { scientist to protect world } \\
\text { and stops the transmission } \\
\text { of corona. Big data } \\
\text { controlled huge datasets } \\
\text { Machine learning and AI } \\
\text { library to track the record } \\
\text { and make the successful } \\
\text { decision, to take right } \\
\text { track. Python has develop } \\
\text { the sector of coding in } \\
\text { easier way. Different } \\
\text { dashboard are used to } \\
\text { track, maintain the record. }\end{array}$ \\
\hline
\end{tabular}




\section{International Journal of Engineering Applied Sciences and Technology, 2020 \\ Vol. 5, Issue 7, ISSN No. 2455-2143, Pages 251-254 \\ Published Online November 2020 in IJEAST (http://www.ijeast.com)}

Figure 4 : Results of pandemic situation

\section{CONCLUSION}

We can say that for 1920 data visualization is pandemic situation is explaining how visualization has proven and improved the situation. In this paper we have discuss and focus as data visualization methods such as graph paper and using technology machine learning, big data and python. Big data is given the data visualization importance in market. As a result in 2020 Covid data visualization and given to impact in the world.

\section{REFERENCES}

[1] R.POLLITIZER (1951), A Summary of the history and Survey of the present distribution of the disease., M.D division of epidemiology, Bull.Org . Mond. Sante Bull , World Health Org. pg(470-529)

[2] Michael Friendly, Wolfgang Karl Karl Hardle, ChunHouh Chen, Antony Unwin (2006) "A Brief History of Data Visualization”, Springer Verlag. pg ( 3- 25)

[3] Zhao-Kaidi, Data Visualization, National University of Singapore.pg(1-6)

[4] Gennady Ardrienko, Steven Drucker (2019), Big Data Visualizationand Analytics:Future Research Challenges and Emerging Applications.pg(1-8)

[5] Thasal, Rajesh, et al. "Information Retrieval and Deduplication for Tourism Recommender System." Information Retrieval 5.03 (2018).

[6] Supriya More, Sharmila Gaikwad, "Secure Cloud using Secure Data De-duplication Scheme", International Research Journal of Engineering and Technology(IRJET), e-ISSN: 2395-0056, Page 793799, May 2018.

[7] Maya gharat, et. al, "Enhancing Speed of Map Reduce Classification Algorithms using Pre-Processing Technique", in International Journal of Advanced Research in Computer Engineering and Technology, Volume 5, Issue 10, October 2016, PP 2482-2487

[8] Maya Gharat, et. al, "Review on Enhancing the Speed of MapReduce Classification Algorithms using preprocessing Technique", International Journal of Computer Science Trends and Technology (IJCST) Volume 4 Issue 2, Mar - Apr 2016 